\title{
Rasch Model Analysis: Teacher Commitment Indicators by Experts Judgment
}

\author{
Ibnu Asakir ${ }^{*}$, Dian Hidayati ${ }^{2}$ \\ 1,2Ahmad Dahlan University, Yogyakarta, Indonesian \\ 1*ibnuasakir2@gmail.com, ${ }^{2}$ dian.hidayati@mp.vad.ac.id
}

\section{Article Info \\ Article history \\ Received October 6, 2021 \\ Revised December 18, 2021 \\ Accepted December 21, 2021}

Keywords: Experts judgment Rasch Model, Teacher commitment,

\begin{abstract}
Teacher commitment is the key to success in educational institutions. The school needs to measure the teacher's commitment to improving the quality of the school. The purpose of this study was to model expert judgment in the reliabilities and validity tests of Teacher commitment instruments using the Rasch model. The study involving 12 experts was conducted using a survey by assessing 18 items. Experts (respondents) are asked to evaluate the consistency of each item to represent one part of the Teacher commitment instrument. Expert judgment results using Rasch model analysis show that the average value of the logit scale is higher than logit 0.0. It is understood that more answering experts agree across a variety of items. The value Cronbach alpha, measuring reliability, i.e., the interaction between the person and the item as a whole, is seen as a value of 0.99 , which means excellent. Person reliability value is estimated at 0.89 , and item reliability is estimated at 0.60 , indicating that the consistency of respondents' answers is good. However, the quality of items in the infrastructure is poor. It shows 17 items recommended to be used as instruments to measure Teacher commitment, while 11 items are advised to be repaired.
\end{abstract}

\section{INTRODUCTION}

Students will never feel the quality of the school without teachers who have a high commitment to education (Razak, Darmawan, \& Keeves, 2009). Commitment is an internal force that encourages teachers to invest more time and energy in school engagement. This willingness to promote schools creates an emotional connection between teachers and schools that ultimately inspires teachers to look for ways to improve the teaching profession and build an effective learning environment to enable students to achieve their targets (Mustafa A, 2017). Teachers' commitment to their duties and professions can be seen from the extent to which the teacher invests his time and soul attachment to his work. (Choi, P. L., \& Tang, 2009). A committed teacher is seen from his character: behaving as a good teacher, behaving instead of just teaching, treating all students as unique human beings, and urging out all his professional responsibilities (Fox, R. B, 1964).

Teachers who commit can also be seen as quality in learning, adaptability to change, consistency of attendance, are tireless, loyal to tasks, live in school, pay attention, and care for learners' progress. (Crosswell, 2006). Teachers who commit will work optimally to devote 
attention, mind, energy, and time to their work so that what they have done is what is expected by the school. (Evi Anggraini, Edi Harapan, \& Tahrun, 2020). Many found low commitment teachers who are less concerned about student problems and have less time and energy to think about their duties. Low teacher commitment will impact teachers leaving their profession (turnover); as a result of research From (Rezky Yulia Safitri, 2013), low commitment will affect the turnover rate, and vice versa, the turnover rate will decrease with high responsibility.

Commitment behavior has been the focus of studies for several years. Usually, this study is widely conducted among sociologists who explore the behavior of individuals and groups in various phenomena such as job recruitment, political behavior, power, bureaucracy, and religion (Reyes. P, 1990). Operationally, commitment is an exchange phenomenon. For example, people tend to stay committed as long as they feel the associated positive benefits, so they are reluctant to lose out (Nir, A. E, 2002). Commitment is motivation and self-efficacy (Chesnut, S. R, \& Burley, H, 2015). Commitment is considered a form of expanded motivation in which targeted social behavior is carried out and maintained. Self-efficacy is related to an individual's belief in performing specific tasks satisfactorily. Thus, more precisely, commitment does not occur quickly or without obstacles related to job satisfaction.

Teacher committees are associated with organizational commitment and teaching commitment. (Robert A. Roe, 2001) Organizational commitment reflects where an employee Commitment is considered an expanded form of motivation in which social behavior recognizes the organization and is bound to its goals. It is a critical work attitude because people commit to working harder to achieve organizational goals and desire to keep working. Sopiah (2008). Work commitment is another term for organizational commitment. In addition, organizational commitment is an essential behavioral dimension that can be used to assess employee tendencies, identify and engage someone who is relatively vital to the organization, and know the desire of organizational members to maintain their membership in the organization and be willing to strive for the achievement of organizational goals and be able to accept the norms that exist in the company.

Organizational commitment is a situation in which an employee takes sides with the organization's goals and desires to maintain their membership in the organization.t (Moorhead and Griffin, 2013). Organizationalorganization can be interpreted as the extent to which an employee experiences a sense of unity with their organization. Furthermore, organizational commitment is an individual willingness to be with an organization with three main characteristics: affective commitment, continuance commitment, and normative commitment (Meyer, J.P., Allen, N.J. and Smith, C.A, 1993).

Teacher commitment there are two things, namely teaching commitment and organizational commitment. Commitment in teaching is significant for the organization of The school the teaching profession-moreover, student learning in improving student learning 
achievement. Commitment is essential in every organization, including schools. (Nir, A. E, 2002). This idea is based on research showing that student achievement is related to the teacher's commitment to teaching. (Park. I, 2005). How much commitment members of the profession (including teachers) have determined the strength of that profession (Fox, R. B, 1964). Also, the teacher's commitment to teaching is significant when the teacher primarily works in the school. As the researchers' results reveal that the commitment of the Master is an essential variable for the success of the school (Heinz, M, 2015) and educational success (Yildiz. Y. \& Celik, B, 2017). The strength of the teaching profession depends on how strongly the teacher is committed to it. In this case, the committed teacher behaves consistently with his educational philosophy.

The teacher's commitment is very close to the teacher's work performance and the teacher's ability to innovate with new ideas and integrate them into practice, always present in school, loyal to the school, and more importantly, the ability to exert a high Influence on the progress of learners and schools (Swarnalatha, S.S, 2016). Committed teachers strive to achieve school success and are emotionally attached to their careers (Ngussa \& Gabriel, 2017).

Committed teachers develop the knowledge, desired attitude, and skills needed (Jane \& Kumar., 2017). Some teachers see their commitment as part of their professional identity, so they enjoy that commitment. However, other teachers feel that a teacher's commitment requires a sizeable personal investment and see it as a job that can handle heavy in living that commitment. A teacher's commitment is a teacher's emotional attachment to the school in which he works to be willing to persevere, identify and engage to achieve school goals. (Hidayt R, Suharyat H, Elizabeth Y, Harjanto S, \& Andi 2018)).

Meyer (1993) points out three components of organizational commitment: (a) Affective Commitment, which occurs when employees want to be part of the organization because of an emotional bond. (b) Continuance Commitment arises when the employee remains in an organization because of es salary or other benefits. (d) Normative Commitment arises from the values of the employee. The employee survives to become a member of the organization because of the realization that commitment to the organization should be made.

While Kanter proposed three forms of organizational commitment: (a) Continuance commitments, a commitment that relates to the dedication of members in the organization's life and produces people who are willing to sacrifice and invest in the organization. (b) Cohesion commitment is a member's commitment to the organization due to social relationships with other members (c) Controlled commitment, which is members' commitment to organizational norms that provide behavior in the direction they want (Sopiah, 2008)) because these norms are able and appropriate in contributing to the behavior they want.

Based on the study of the above concepts and theories, the teacher's commitment is 
the expression and effort of the teacher in a continuous-time in advancing learners and schools. The existence of loyalty to students and schools is what is intended with the excellent committee; it can improve the quality of the school itself.

\section{The Proposed Method/Algorithm}

This research is research to find expert judgment in developing instruments on the Teacher Commitment variable. Expert assessment in the development of instruments is critical. However, the expert review has been conventionally involved in determining the item's suitability or evidence of validity related to the content (Safrit, M. J., \& Wood, T. M, 1995). In measurements that refer to criteria, standardized or test criteria are also often determined by expert assessment, thus playing an essential role in the new assessment format (Dunbar, S. B., Koretz, D. M., \& Hoover, H. D, 1991).

Rasch model, introduced by Linacre (Linacre, J. M, 1989), is based on the welldeveloped Rasch model (Zhu, W., \& Cole, E. L, 1996); also known as the one-parameter logistics model, it is a measurement model in the framework of an item response theory. (IRT). The Rasch model is a two-sided model typically used to model the relationship between the nature of an examiner and their responses, e.g., right and wrong, to a test item. If the examinee's ability is higher than the difficulty level of the test question, the chances of the examinee to complete the problem successfully will be greater; Conversely, if the ability is lower than the difficulty, the options become more negligible. In the context of assessing the item's representational content, two aspects are the underlying nature of the expert appraiser and the quality of the test item for good or bad. This study was conducted by examining the indicator of an instrument item according to expert research, where researchers have not widely done this study.

\section{Design, Samples, and Instruments}

This research was conducted by assessing experts (expert judgment) on the teacher's commitment instrument-as many as 12 experts were sampled in this study. The design of the research is quantitative with survey methods. The study measured one variable, the commit. The distinctive aspects of respondents measured in this study were gender, educational institutions, educational levels. The type of measurement scale used is the LIKERT rating scale, with four question options.

\section{METHOD}

Research is carried out by assessing experts (expert judgment). Rasch modeling is used for the analysis of questionnaire data. This type of research is quantitative research with research survey methods measuring one variable, namely, commit. The distinctive aspects of respondents measured in this study were gender, length of work, last level of education, age, 
and lecturer status. The type of measurement scale used is the LIKERT rating scale, with four question options.

The measure used to measure teacher commitment there are 18 measures, taken from several sources in the literature review, namely: Maintaining relationships with parents of students in maintaining parental trust in the School, Monitoring the development and progress of learners, Always trying to be present on time. , Proud to tell this school to friends as an excellent organization to work for, Willing to make extra effort (help complete work outside of obligations) in addition to the work that has been determined to support the success of the School, Have a concern about the fate of this School, Happy to choose this school as my workplace compared to other schools that I considered at the time I joined, Feel comfortable in this school institution as a place of education for me, Maintaining the excellent name of the school through attitudes and behaviors, Helping the academic progress of the School, Foundation paying attention to my family education, Maintaining a conducive climate in School, Finding a match between the values that I hold with the values in this school, this school is the best organization of all institutions that allow me to work, Accepting almost all types of work assigned to me in order to still work in this organization / school, this school provides the best inspiration for me in achieving work achievement, committed to being a good teacher, and provide helpful subject matter for educated participants.

The raw data uses measurement results from questionnaires in ordinal scales, then transformed in logit form into interval scales through statistical software, Winsteps. This type of analysis assesses experts using Rasch modeling. Rasch modeling is an analytical tool that can test the validity and reliability of research instruments by simultaneously testing the suitability of persons and items. 


\section{Results and Discussions}

\subsection{Variable Maps}

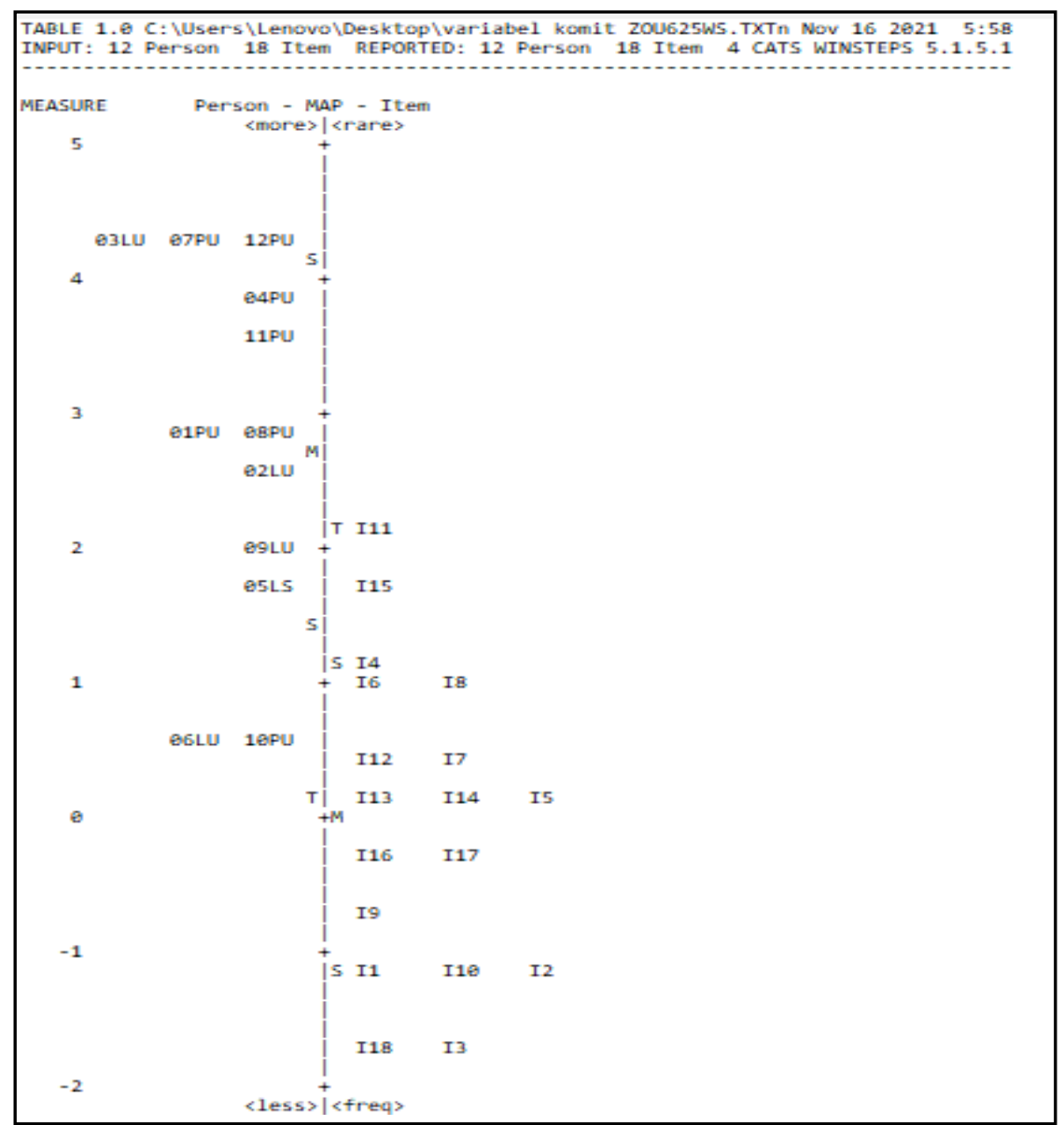

Figure 1. variable maps

The image above shows that the left side of the line is the entire person, while the right of the line represents the breadth of the item. It can be known that the person who most agrees to person 03LU, 07PU, and 12PU, while the person who is most challenging to approve 06LU and $10 \mathrm{PU}$. The items showed that the most challenging items respondents approved were 111 , while the most accessible items supported 13 and 118 .

\subsection{Reliability and Validity}

Understanding the reliability and validity of the Rasch Model provides a complete picture characterized by three settings, namely Person Reliability, Item Reliability, and Alphacronbach. 


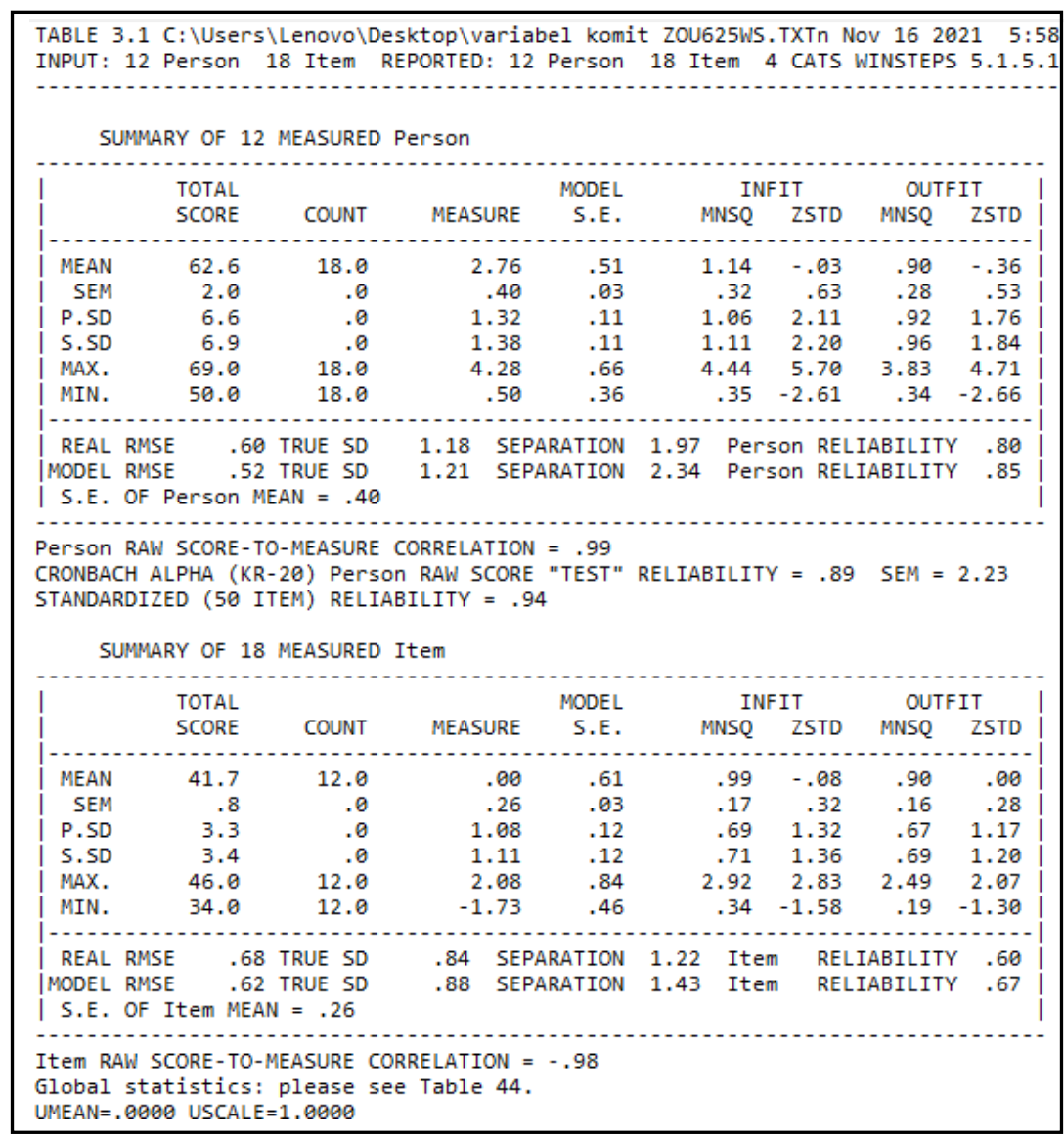

Figure 2. Summary Statistics

The image above explains the overall quality of the respondent. In Contrast, this welder also shows the quality of the instrument used by looking at the interaction between the person (respondent) and the item. To understand summary statistics can be used five ways, including (Suminto B dan Widhiarso W, 2014); First score Person Measure looks logit number +2.76 , this shows the average value of respondents in the Teacher commitment instrument. An average value higher than logit 0.0 indicates a tendency for respondents to answer more in agreement across various items. The second score, Cronbach alpha, measuring reliability, i.e., the interaction between the person and the item as a whole, is seen with its value of 0 . 99 is very good. The three-person reliability values are estimated at 0.89 , and the reliability item is estimated at 0.60 , it can be concluded that the consistency of respondents' answers is good, but the quality of items in the instrument is poor.

Fourth score INFIT MNSQ and OUTFIT MNSQ on the person's value is 1.14 and 0.90 , where the ideal value is one means respondent is a person who has good skills because the value is close to 1. While the INFIT ZSTD and OUTFIT ZSTD values for items are

-0.03 and -0.36 , close to 0 , meaning good. The same is seen in the item table-fifth To group people and items viewed at separation values. The separation value in person is 1.97 with the formula $((4 \times 1) 97)+1) / 3=2.96$ rounded to 3 means there were three groups of respondents in the study. The greater the value of separation, the quality of the instrument in 
terms of overall respondents and items, because it can identify the respondent group and the group of items.

\subsection{Item Measure}

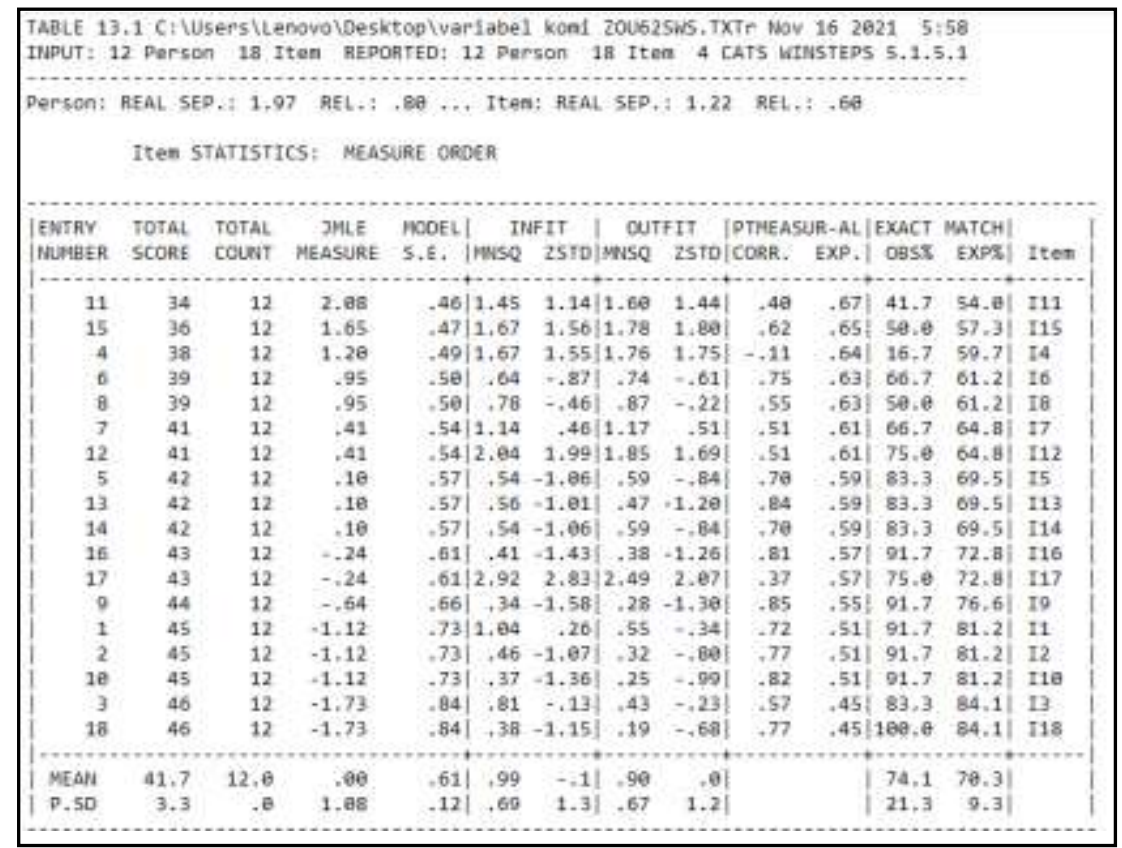

Figure 3. Reliability Item

The output of the measured item indicates the order of items that are difficult for the respondent to approve until the respondent quickly approves the item. In the output above for item No. 111 with a value of +2.08 logit indicates this is the most challenging item approved by respondents, while item no. 118, with a value of -1.73 , was the most accessible item approved by respondents.

\subsection{Item Fit order}

Item fit orders have the function to measure or provide information related to items that match or fit (fit) and items that do not match or do not fit (misfit); two things determine Boone et al. (2014), fit or misfit items; first score Outfit Mean Square (MNSQ) between: $0.5<M N S Q<$ 1.5 and second score outfit Z-standard (ZSTD) between: $-2.0<$ ZSTD $<+2.0$. If the item items on both criteria are not met, it means that the problem item is not good and needs to be revised, replaced, or eliminated.

Figure 4 can be interpreted in three respects; The first fit and misfit item can be used the INFIT MNSQ value of each item; the average value and standard deviation are summed then compared. In the image above, the mean or average value of the logit is 0.99 , with the SD value being 0.69 if summed up the value of $0.99+0.69=1.68$, then two items are large above 1.68, namely item 117 (2.92) and 112 (2.0 4). Second, check for unsuitable items (outliers or misfits) can look at the MNSQ OUTFIT value whether it is located between $0.5<$ $M N S Q<1.5$, by looking at this criterion, then item no. 117 (2. 49), $112(1.85), 115$ (1. 78), 14 (1.76), 
$111(1.60), 113(0.47), 12(0.32), 116(0.38), 118(0.19), 13(0.43) .110(0.25)$ and item 19(0.28) required repair. Third, by looking at the ZSTD OUTFIT value, the value should be in the range of $-2.0<$ ZSTD < 2.0; back by looking at this standard, item no. 117 (2.07) is an item estimated to be misfit, so it needs to be repaired or eliminated.

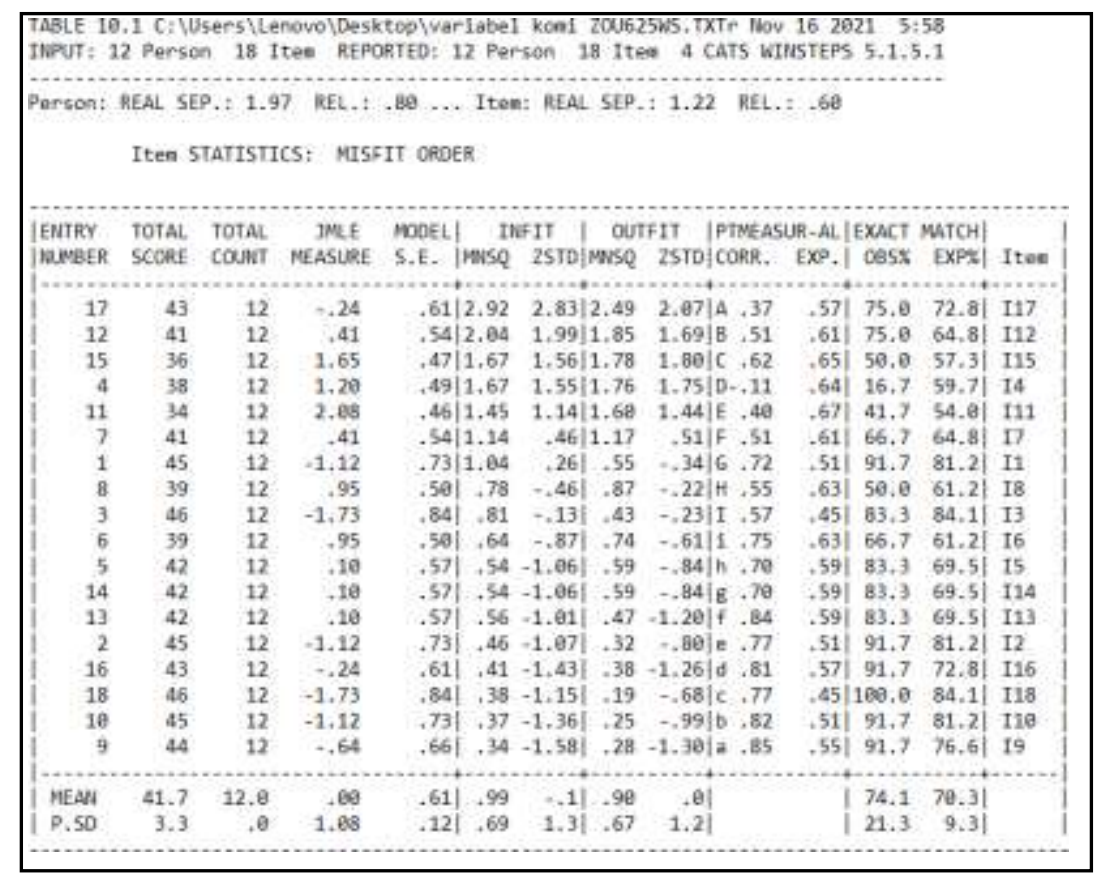

Figure 4. Results score Fit Item

\subsection{Unidimensionalitas}

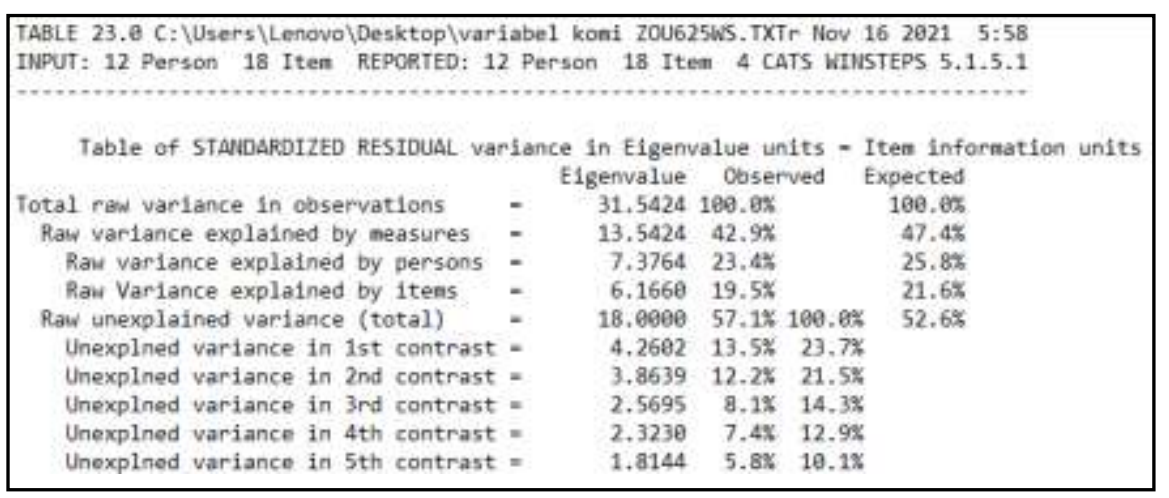

Figure 5. Unidimensionality Values of School Quality Items

This stage is crucial because it ascertains whether the instrument item developed can measure what will be measured, meaning to ascertain whether these 18 items are correctly measuring Master's commitment or not. The base used also uses Principal Component Analysis from residual.

From Figure 5, the number of feeder results from natural variance data is $42.9 \%$. It indicates that the unidimensionality requirement of at least $20 \%$ can be met if the value is more than $40 \%$, meaning better. Another indication that indicates the entire unidimensional item is that the unexplained variance ideally does not exceed $15 \%$. 


\subsection{Rating scale}

After confirming that the entire item is in one(unidimensional)group, then the next test is to verify whether the rank used to measure expert judgment is confusing or not.

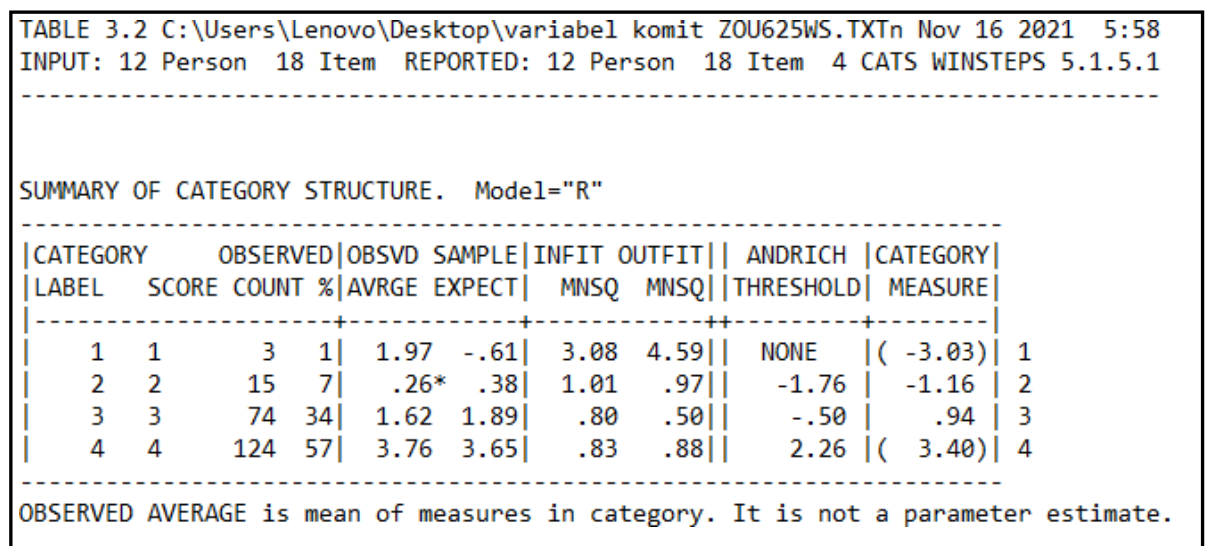

Figure 6. Proper Ranking Scale Determination for Teacher Commitment

In Figure 6, it appears that the average observation starts from logit 1.97 for a score of 1 , is highly irrelevant, and continues to increase until logit 3.76 to be highly relevant. It is seen that on all select 1, 2, 3, and 4, there is no up and down, meaning that the pattern continues to increase from strongly disagreeing to strongly agreeing. Another measure to ensure the right ranking scale is Andrich.

Threshold, where it appears that the AT value starts from none then negative and leads sequentially until the option strongly agrees. Therefore, a four-rank scale strongly disagrees until strongly agreed to be advised for expert augment measurements.

\subsection{Item repair}

Item repair is indispensable, as the Cronbach alpha value on item 0.6 indicates a less good value. It indicates that the item is fragile. The items that need improvement are 117112 , $115,14,111,113,12,116,118,13.110,19$ \& The item that makes experts whisper is item 117.

From the results of the expert assessment, instruments that need to be improved include; Maintaining a conducive climate in the school, Accepting almost all types of work assigned in order to still work in this organization/school; this school is the best organization of all institutions that allow working, The Foundation pays attention to the family education, Finding a match between the values that hold with the values in this school, this school provides the best inspiration in achieving work achievement, Provide the valuable subject matter for educated participants, Help the academic progress of the school, Always try to be present on time. While items that are removed or replaced are committed to being a good teacher

\section{CONCLUSIONS}

Expert judgment in developing commitment instruction quantitatively by the Rasch 
model. Although group membership did not affect the data-model match, its impact on item ratings was detected. Rasch models do not facilitate the examination of the accuracy of experts in assessing instruments, thus achieving an objective, or appraiser-free, evaluation of items. The Rasch model contributes to the test developer's Understanding of the assessment process and provides additional quantitative support for including and removing such instrument items.

The results of the Rasch model analysis can be known in the most helpful persons 03, 07, and 12. While the teacher commitment instrument items that are the most difficult to approve respondents are 111 , while the most easily approved items are 13 and 118 . On the logit scale known to be higher than logit 0.0 , it can be understood that the tendency of more answering experts agrees across various items. While score Cronbach alpha, measuring reliability, i.e., the interaction between the person and the aitem as a whole, is seen its value of 0.99 is very good. Person reliability values are estimated at 0,89 , and reliability items are estimated at 0 . 60 shows that the consistency of expert answers is good, but the quality of items in the instrument is still poor. The items that need improvement are $117112,115,14,111,113,12,116$, $118,13.110$ and item 19. At the same time, the item that makes experts mute is item 117, so this item is guaranteed to be replaced or eliminated.

\section{REFERENCE}

Chesnut, S. R, \& Burley, H. (2015). Self-efficacy as a predictor of commitment to the teaching profession: A meta-analysis.Educational Research Review, Vol. 15. 116.

Choi, P. L., \& Tang, S. Y. F. (2007). Teacher commitment trends: Cases of Hong Kong teachers from 1997 to 2007. Journal Teaching and Teacher Education, Vol 25. 767- 777.

Crosswell, L. "Understanding teacher commitment in times of change. "Faculty of The Education Queensland University of Technology. 2006.

Dunbar, S. B., Koretz, D. M., \& Hoover, H. D. (1991). Quality control in the development and use of performance assessment. Applied Measurement in Education, Vol. 4, 289-303.

Evi Anggraini, Edi Harapan, \& Tahrun. (2020). Pengaruh Tunjangan Sertifikasi dan Komitmen Pada Tugas Terhadap Prestasi Kerja Guru. Jurnal Manajemen Pendidikan. Vol. 2 No.1

Fox, R. B. (1964). The Committed Teacher ."Department of Education, Northern Illinois University, the Association for Supervision and Curriculum Development.

Fox, R. B. (1964). The Committed Teacher ."Department of Education, Northern Illinois University, the Association for Supervision and Curriculum Development.

Heinz, M. (2015). Why choose to teach? An international review of empirical studies exploring student teachers' career motivations and levels of commitment to 
Hidayt R, Suharyat H, Elizabeth Y, Harjanto S, Andi H. (2018). Optimalisasi Budaya Mutu Sekolah Untuk Meningkatkan Komitmen Guru. Jurnal Manajemen Pendidikan Vol.6, No.2. DOI: 10.33751/amp.v6i2.786. 2018

Jane \& Kumar. (2017). Teacher commitment and student achievement in chemistry at the higher secondary level, International Journal of Current Research and

Linacre, J. M. (1989). Many-faceted Rasch measurement.Chicago: MESA Press

Meyer, J.P., Allen, N.J. and Smith, C.A. (1993) "Commitment to Organisations and occupations: Extension and test of a Three-Component Conceptualisation," Journal of Applied Psychology, 78, 4, pp.538-551.

Meyer, J.P., Allen, N.J. and Smith, C.A. (1993). Commitment to Organisations and Occupations: Extension and test of a three-component Conceptualisation, Journal of Applied Psychology, 78, 4, pp.538-551.

Modern Education. https://doi.org/10.5281/zenodo.263072.

Mustafa Altun. (2017). The Effects of Teacher Commitment on Student Achievement. International Journal of Academic Research in Business and Social Sciences, Vol. 7, (11). Ngussa \& Gabriel. (2017). Participation in Decision Making and Teachers' Commitment, American Journal of Educational Research. DOI: 10.12691/education-5-7-17

Nir, A. E. (2002). School-based management and its effect on teacher commitment. International Journal of Leadership in Education.Vol. 5 (4). 32.

Nir, A. E. "School-based management and its effect on teacher commitment. "International Journal of Leadership in Education.Vol. 5 No. 4. 32. 2002

Park. I. (2005). Teacher commitment and its effects on student achievement in American high schools."Educational Research and Evaluation, Vol. 11 (5). 461-485.

Razak, N. A., Darmawan, I. G. N., \& Keeves, J. P. (2009). Teacher Commitment. International Handbook of Research on Teachers and Teaching", Vol. 21.

Reyes. P. (1990). Linking commitment. Performance and productivity. In P Reyes (Ed.). Teachers and their workplace: Commitment, performance, and productivity (pp. 15- 21) san Francisco, CA: SAGE.

Rezky Yulia Safitri. (2013). Hubungan Antara Kepuasan Kerja dan Komitmen Organisasi dengan Intensi Turnover Pada Guru, Character Journal, Vol. 01, No. 02.

Robert A. Roe. (2001). Competence Human Resource, Yogyakarta : Gajah Mada University Press

Safrit, M. J., \& Wood, T. M. (1995). Introduction to measurement in physical education and exercise science. St. Louis, MO: Mosby.

Sopiah. (2008). Perilaku Organisasional. Yogyakarta: Penerbit Andi Moorhead and Griffin. (2013). Perilaku Organisasi. Jakarta: Salemba Empat

Suminto B dan Widhiarso W. (2014) "Aplikasi model Rash Untuk Penelitian IImu-IImu Sosial". Bandung. 
Swarnalatha, S.S. (2016). Work Commitment of Secondary School Teachers. International Journal of Indian Psychology, Vol. 3 (4), pp 99-156.

Teaching. Educational Research and Evaluation. Vol. 21 (3), 258 - 297

Yildiz. Y. \& Celik, B. (2017). Commitment to the teaching profession, International Journal of Social Sciences \& Educational Studies, Vol. 4 (2). pp $93-97$

Zhu, W., \& Cole, E. L. (1996). Many-faceted Rasch calibration of a gross motor instrument. Research Quarterly for Exercise and Sport, 67, 24-34. 